

رئبس القسمـ: أ .د / ابراهيم محمد حسن سكر.

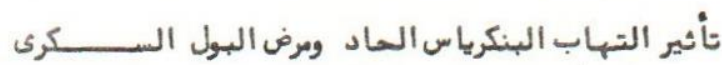

$$
\begin{aligned}
& \text { التجريبى على منحنى الجلكوز فى البقر والجاموس البول البراد }
\end{aligned}
$$

سمير حسن ، سيد العمروسى ، أهمد عامســــر، عاطف بلبــــلـل ، سمير مختــــار





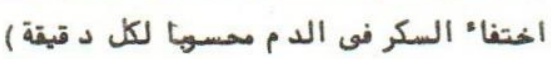



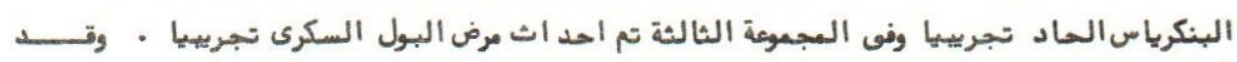

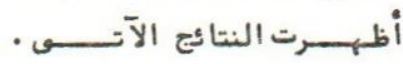

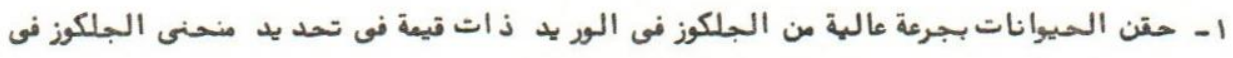



r- r انخفض منحنى الجلكوز فو المجموعة الثالثة عنه فى المجموعة الا ولى والثانية .



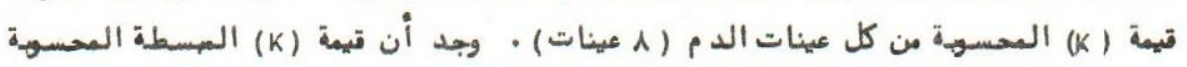

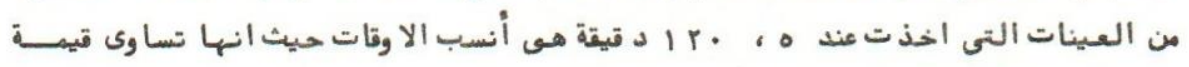





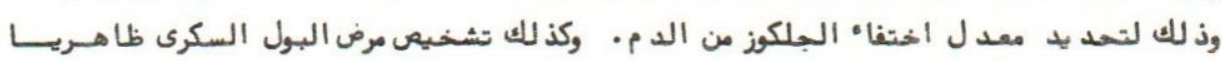


Dept. of Medicene \& Poultry Diseases,

Faculty of Vet. Med., Assiut University,

Head of Dept. Prof. Dr. I.M. Sokkar.

\title{
EFFECT OF INDUCED ACUTE PANCREATIIIS AND INDUCED EXPERIMENTAL DIABETS ON GLUCOSE TOLERANCE IN CATTLE AND BUFFALOES
}

(With 5 Tables)

\author{
By
}

\author{
M.S. HASSAN; S. EL-AMROUSI; A.A. AMER; A.E. BOLBOL * and S.A. MOKHTAR* \\ (Received at $24 / 4 / 1982$ )
}

\section{SUMMARY}

\begin{abstract}
Acute pancereatitis and diabetes were experimentally induced in cattle and buffaloes to study the effect of the diseases on glucose tolerance. The $(K)$ value (glucose disappearance coefficient, measured in percentage, decrease of glucose/min) was calculated from the higher dose intravenous glucose tolerance test.

Fifteen animals were allotted to three groups of five animats each as follows: Group l: control, Group: II pancreatitis affected animals, Group: III diabetic animals. The results indicated that:

1. High dose intravenous glucose-tolerance test was an effective tool for determining glucose-tolerance in cattle and buffaloes.

2. Glucose tolerance of group III was markedly decreased compared with that of group 1 \& Il. To determine if a simplified (K) value (calculated using 2 or 3 blood samples) could approximate the $(K)$ value (calculated using 8 blood samples) simplified (K) values were derived from 5 and 120 minute blood sample values. These values closely approximated the standard (K) values, indicating the simplified value may be used in the clinical situation. The standard $(\mathrm{K})$ value, however, is preferred for investigative work.
\end{abstract}

\section{INTRODUCTION}

Pancreatitis is the commonest predisposing cause of diabetes millitus (ANDERSON and LOW, 1965; DIXON and SANFORD, 1961; MEIER, 1960 and PERMAN and STEVENS, 1969). The inflammatory process may lead to vascular damage, resulting in ischaemia and necrosis of both acinar and endocrine tissue. Repeated episodes of pancreatitis may then results in diabetes mellitus. Even though pancreatitis and diabetes are usually thought of as separate clinical entities, they commonly occur concurrantly (Cotton, CORNELIOUS and THERAN, 1971).

GREVEet al. (1973) reported experimentally incuced acute pancreatitis with concurrent diabetes mellitus in 8 dogs. When they coexist, diabetes mellitus is usually correctly diagnosed, but pancreatitis may be overlooked because of a lower index of suspicious for that disease. Diabetes may develop during the first episode of pancreatitis but it more often occurs weeks or months later (MAHAFFEY and ANDERSON, 1976).

GREVE and ANDERSON, (1973) studied high dose intravenous glucose tolerance test (H.I.V. G.T.T.) modified according to DYCK and MOORHOUSE, (1966) in normal, prediabetic and overtly diabetic dogs and in dogs with juvenile pancreatic atrophy. They described the procedure for the H.I.V. G.T.T. ( $1 \mathrm{gm}$. of glucose/kg. Bwt); discussed the calculation and the significance of the $(K)$ value (glucose disappearance coefficient), and set the guide lines for interpretting the $(K)$ value as follows: $K$ greater than $2=$ Normal, $K$ between 1.9 and $1.1=$ prediabetic and $K$ equals to or less than $1.0=$ over diabetes.

The primary purpose in the present study was to determine the effect of experimentally induce acute pancreatitis and glucose tolerance of cattle and buffaloes; second to evaluate further the H.I.V. G.T.T. as a screening test for pancreatic inflammatory disease in cattle and buffaloes and third to determine whther the standard $(\mathrm{K})$ value, determined on the basis of 8 blood samples, could be closely approximated by calculating a simplified (K) value for 2 or 3 blood samples.

* Dept. of Surgery, Fac. of Vet. Med., Assiut University, Head of Dept. Prof Dr. M.H. El-Guindi.

** Dept. of Animal Production, Fac. of Agric., Assiut University, Head of Dept. Prof. Dr. H. El-Hammady. 


\section{MATERIAL and METHODS}

15 male cattle and buffaloes ( 8 cattle and 7 buffales) of varying weight ( $300-400 \mathrm{kgs}$ ) aging between 1.5 3.5 years each were alloted to 3 groups of 5 animals each as follows:

Group 1 : Control (3 Cattle and 2 buffaloes)

Group II : Acute pancreatitis (2 Cattle and 3 buffaloes)

Group III: Induced acute diabetes ( 3 Cattle and 2 buffaloes)

The animals were put under clinical observation for 3 months before experiment. The animals were examined every two weeks to insure that the animals were healthy and free from external, internal and blood parasites.

The H.I.V. G.T.T. modified according to DYCK and MOORHOUSE, (1966) was performed on days $1,7 \& 15$ after experimental induction of mentioned cases. Glucose ( $1 \mathrm{gm} / \mathrm{kg}$ Bwt. as a $50 \%$ solution) was injected very rappidly into jugular vein. That vein was not used again the same day. All blood samples were collected from the jugular vein at $0,5,10,20,30,60,90,120$ and 180 minutes after the injection of glucose.

Collected blood samples were prepared for blood chemical determination on the same days that the glucose tolerance tests were performed. The following blood chemical analytical values were determined: glucose, amylase and lipase (HASSAN, 1980). Acute pancreatitis was induced by injection of $25 \mathrm{ml}$. of chloroform in different sites in the area of the pancreatic parenchyma. The surgical procedure to reach the pancreas was adopted after the method of BROBST, et al., (1970). Induced diabetes was performed in the third group after the method described by HASSAN, (1980).

Regression analysis was performed using within-group-day data collected from the glucose toterance test. The model used was $\log Y=\alpha \pm B t$. where $Y=$ glucose, $\alpha=$ a constant, $B=$ slope $\& t=$ Time.

The $K$ value was defined as $-B \times 100$.

Regression equqtions of subsets of the data were used to determine if fewer blood samples could be used to calculate $(K)$ values (simplified $K$ values) which would consistently approximate the standard (K) value. Differences between the standard $K$ values and the simplified $K$ values and the simplified $K$ values were calculated. The data collected from each of the measured variable (fasting glucose, amylase and lipase) and the individual (K) values were used as a repeat-measure analysis of variance (ANOVA). The means of the measured variables and the (K) values of each group were also calculated for each test day.

When a significant $F$ test was noted in the analysis of variance, the means were subjected to a Fisher's least significant difference (LSD) test. The level of significance was 0.05 .

\section{RESULTS}

High Dose Intravenous Glucose Tolerance Test:

There were no significant changes in the glucose tolerance of animals in Group I (Table 1). In group II, the mean $(K)$ values did not change significantly from day $I$ to 7 to 15 but the $(K)$ value was significantly lower than in group I. The glucose tolerance of group III (Table 1) was highly significantly decreased after induced diabetes. The mean $(K)$ values of group III was significantly lower that of group II.

All individual (K) values of group I were greater than 2.00. The maximums and minimums of individual (K) values of group II were 1.9 and 1.5. On the other hand the maximums and minimums of individual (K) values of group III were 0.9 and 0.7 .

Simplified $(K)$ values were also calculated, using only 2 or 3 time samples post glucose injection. These combinations were used 5 and $60 \mathrm{~min}, 5$ and $90 \mathrm{~min}, 5$ and $120 \mathrm{~min}, 10$ and $60 \mathrm{~min}, 10$ and $90 \mathrm{~min}$ and 10 and $120 \mathrm{~min}$, 5, 60 and $120 \mathrm{~min}$. and 10,60 and $120 \mathrm{~min}$. Table (V) shows that the (K) values (calculated using 5, 60 and 120 $\mathrm{min}$ ) were closed to the standard $(\mathrm{K})$ values (calculated using all 8 samples) in cases of using 3 blood samples. On the other hand when 2 blood samples were used the $(\mathrm{K})$ values calculated using $5 \& 120 \mathrm{~min}$. samples wee closest to standard $(K)$ values. 


\section{GLUCOSE TOLERANCE IN CATTLE AND BUFFALOES}

The results of festing glucose amylase and lipase tests are presented in Tables. II, III and IV respectively).

\section{DISCUSSION}

Glucose Tolerance and Standard K Values:

The mean (K) values of group III (Table 1) decreased sharply after induced diabetes than in the control group (Group 1). The injection of alloxan produced a selective necrosis of the Beta cells of pancreatic islets and that much of the readily avaliable insulin had been exhausted. The mean fasting blood glucose was highest and the mean (K) value was also lowest than the control group.

The mean (K) value of group II decreased than control one. Acute pancreatitis caused by chloroform injection in pancreatic tissue was the major factor in decreasing the glucose tolerance due to decreasing Beta cells function and number. MAHAFFEY and ANDERSON, (1976) explain the decreased mean (K) value on the bases that soon after surgical operation some beta cells were probably undergoing necrosis. So when the glucose tolerance test was being performed mean (K) value decreased. By the criteria of GREVE and ANDERSON, (1973) the lowest mean K value (Table 1) of group II would be classified in the prediabetic group.

The Mean serum amylase activity and mean serum lipase activity in group II were significantly increased after induced pancreatitis, produced by chloroform injection, than that group III injected by alloxan, thus indicating, that the acinar cells in group II was severely destructed. HASSAN, (1980) reported that injefction of alloxan produced a selective necrosis of B-cells of pancreatic islets and did not affected the acinar cells tissue, thus the pancreatic enzymes (amylase, lipase) were not affected in group III.

Simplified (K) values calculated using 5 \& $120 \mathrm{~min}$. samples produced $(\mathrm{K})$ values close to the standard. Six of 9 times the simplified (K) values calculated from the 5-120 minutes samples combination were closest to the standard (K) value. Six times showed that the difference was less than $(0.1)$, the largest difference was $(0.2)$. In all instances, the $R$ (correlation coefficient) was highest when the 5 \& 120 minuts sample were used to plot the line from which the simplified $(\mathrm{K})$ value was calculated.

The next best combination was that of 5, 60 and $120 \mathrm{~min}$. Six of 9 times the difference was less than 0.10 the largest difference was 0.27 . The $R$ calculated from this combination equals to that of the 5 \& 120 min. sample combination.

Differences between the other simplified $(\mathrm{K})$ values and the standard were great to be acceptable. The poorest combination was that using 10 - and $60-\mathrm{min}$. samples.

\section{REFERENCES}

Anderson, N.V. and Low, D.G. (1965): Diseases of the canine pancreas. A comparative summary of 103 cases. Animal hosp., 1, 189-194.

Brobst, D.; Ferguson, A.B. and Cartus, M. (1970): Evaluation of serum amylase and lipase activity in experimental in duced pancreatitis in the dog. J.A.V.M.A., 157, 1697.

Cotton, R.B.; Cornelious, L.M. and Theran, P. (1971): Diabetes mellitus in the dog. A clinicopathologic study. J.A.v. M.A., 159, 868-870.

Dixon, J.B. and Sanford, J. (1961): Canine diabetes mellitus. A report of fourteen cases. J. Small Anim. Practi, 2, 9-17.

Dyck, D.R. and Moorhouse, J.A. (1966): High dose intravenous glucose tolerance test (H-IVGTT) in dogs. J. Clin. Endocrinol. Metab., 26, 1033-1038.

Greve, T. and Anderson, N.N. (1973): The high dose intravenous glucose tolerance test (H.I.V. G.T.T.) in dogs. Nord. Vet. Med., 25, 436-445.

Greve, T.; Dayton, A.D. and Anderson (1973): Acute pancreatitis with co-existent diabetes mellities. An experimental study in the dog. Am. J. Vet. Res., 34, 939-945. 


\section{M.S. HASSAN, et al.}

Hassan, M.S. (1980): Some studies on pancreatic function in cattle and buffaloes. These M.V.D. Faculty of Vet. Med. Assiut Univ.

Mahaffey, M.B. and Anderson, N.V. (1976): Effect of staphylococcal alpha toxin pancreatitis on glucose tolereance in the dog. Am. J. Vet. Res., 37, 947-952.

Meier, H. (1960): Diabetes-mellitus in animals. Diabetes, 9, 485-489.

Perman, V. and Stevens, J.B. (1969): Clinical evaluation of the acinar pancrease of the dog. J.A.V.M.A.,155,2053-2058.

Table (1): Least significant difference (LSD) test of mean $\mathrm{K}$ values of high-dose intravenous glucose tolerance test (H.I.V.G.T.T.) in cattle and buffaloes with experimentally induced pancreatitis, diabetes and control.

\begin{tabular}{cccc}
\hline Day & Group I & Group II & Group III \\
\hline 1 & $x^{2.20^{a}}$ & $y^{1.69^{b}}$ & $z^{0.83^{c}}$ \\
\hline 7 & $x^{2.19^{a}}$ & $y^{1.60^{b}}$ & $z^{0.76^{c}}$ \\
\hline 15 & $2.21^{a}$ & $y^{1.70^{b}}$ & $z^{0.82^{c}}$ \\
\hline
\end{tabular}

Non-significant grouping have same letter, a, b, and c, represent differences within days (across) while $x, y$ and $z$, represent differences within groups. (down).

Table (II): The LSD test of mean fasting blood glucose concentration $(\mathrm{mg} / 100)$ in cattle and buffaloes with experimentally induced pancreatitis, diabetes and control.

\begin{tabular}{|c|c|c|c|}
\hline Day & Group 1 & Group II & Group IIl \\
\hline \multirow{3}{*}{1} & $a$ & b & c \\
\hline & $52 \quad 59$ & 59 & 87 \\
\hline & $x$ & y & z \\
\hline \multirow{3}{*}{7} & a & b & c \\
\hline & 45 & 62 & 170 \\
\hline & $\mathrm{x}$ & y & $z$ \\
\hline \multirow{3}{*}{15} & a & b & c \\
\hline & 48 & 60 & 170 \\
\hline & $\mathrm{x}$ & $y$ & $z$ \\
\hline
\end{tabular}

Non-significant grouping have same letter: a, b and c represent differentes within days (across) $x, y$ and $\mathrm{z}$ represent differences within group (down).
Table (III): The LSD test of mean amylase values $(\mathrm{U} / 100 \mathrm{ml})$ in cattle and buffaloe with experimentally induced pancereatitis, diabetes and control.

\begin{tabular}{cccc}
\hline Day & Group I & Group II & Group III \\
\hline 1 & $x^{67.6^{a}}$ & $y^{149.4^{b}}$ & $x^{78}$ \\
\hline 7 & $x^{72.2^{a}}$ & $y^{120.6^{b}}$ & $x^{68.2^{a}}$ \\
\hline 15 & $x^{69.5} y^{115.5^{b}}$ & $x^{84}$ \\
\hline
\end{tabular}

Non-significant grouping have the same letter: a and b represent differences within days (across); $\mathrm{x}$ and y represent differences within group (down).

Table (IV): The LSD test of mean lipase values $(\mathrm{ml}$ of $0.05 \mathrm{~N} \mathrm{Nach})$ in cattle and buffaloes with experimentally induced pancreatitis diabetes and control.

\begin{tabular}{cccc}
\hline Day & Group I & Group II & Group III \\
\hline 1 & $x^{0.74^{a}}$ & $y^{2.00^{b}}$ & $x^{0.72^{a}}$ \\
\hline 7 & $x^{0.86^{a}}$ & $y^{2.00^{b}}$ & $x^{0.59^{a}}$ \\
\hline 15 & $x^{0.65^{a}}$ & $y^{1.7}$ & $x^{0.70}$ \\
\hline
\end{tabular}

Non-significant grouping have the same letter; a and b represent differences within days (across); $\mathbf{x}$ and y represent differences within group (down). 
Table V: Glucose Tolerence Of Cattle And Buffeloes With Experimently Induced Pencreatitis, Induced Disbetes And Control (Normal Animals)

\begin{tabular}{|c|c|c|c|c|c|}
\hline Day & $\begin{array}{l}\text { Sample times } \\
\text { (min. After } \\
\text { (MIuoose Injeolion) }\end{array}$ & $\alpha$ & K & $R^{2}$ & $\begin{array}{l}\text { Standard } \mathrm{K} \text { values } \\
\text { - Simplified } \mathrm{K} \\
\text { values }\end{array}$ \\
\hline
\end{tabular}

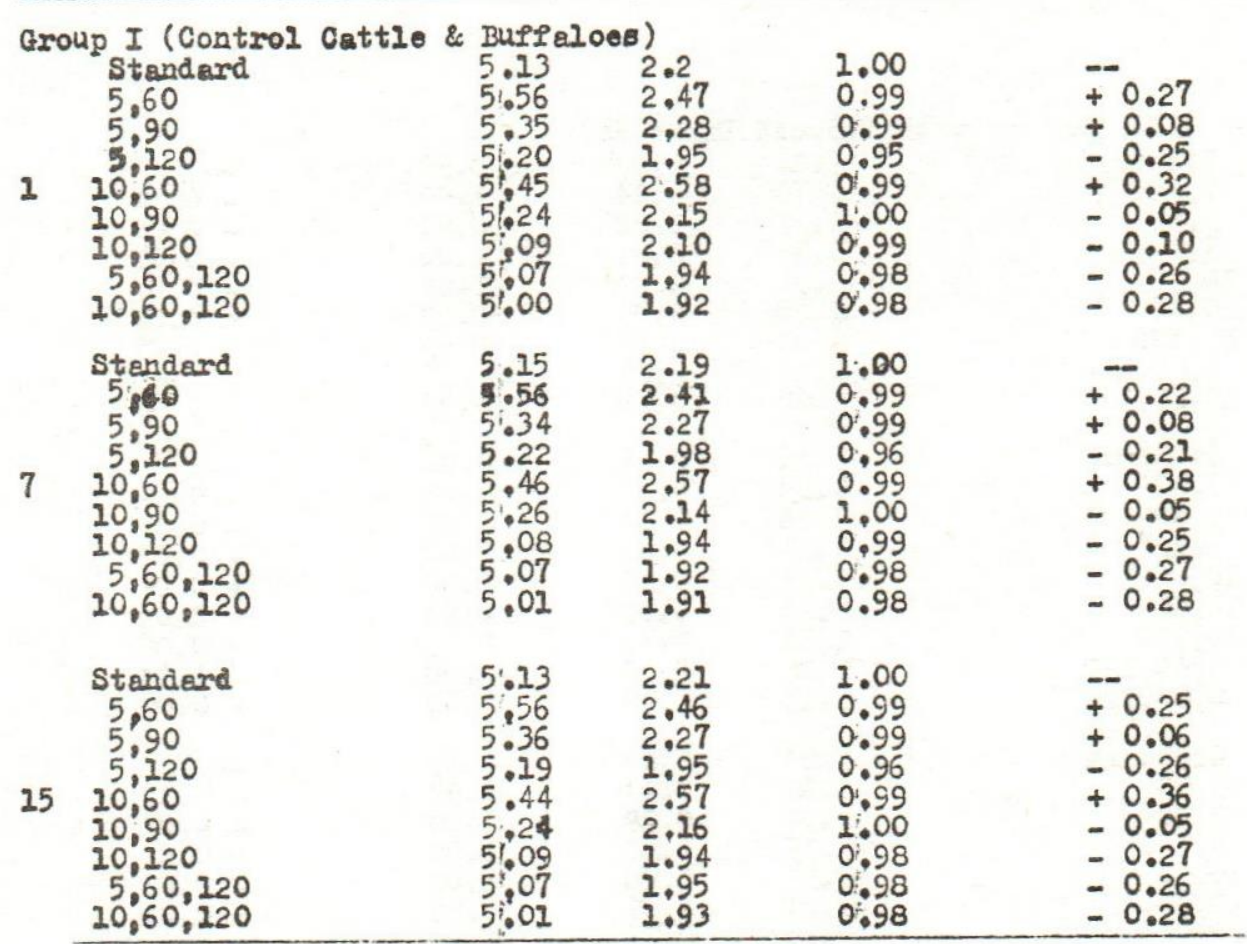

Croup II (Animals with Induced Pancreatit18) Standent

$\begin{array}{lcl}\text { nduced } & \text { Pancreatitis) } \\ 5.57 & 1.67 & 1.00 \\ 5 ! .80 & 2.2 & 1.00 \\ 5.80 & 1.8 & 0.99 \\ 5.45 & 1.7 & 0.99 \\ 5.75 & 1.95 & 0.95 \\ 5.55 & 1.9 & 0.99 \\ 51.41 & 1.6 & 0.99 \\ 5.36 & 1.6 & 0.99 \\ 5.33 & 1.6 & 0.99\end{array}$

$=0.51$
$=0.11$
$=0.01$
$=0.26$
$=0.21$
+0.09
+0.09
+0.09

$1 \quad 10,90$

$$
5,60
$$

5,90

10,60

$5,60,120$

$10,60,120$

$\begin{array}{ll}5.68 & 1.60 \\ 5.89 & 1.96 \\ 5.69 & 1.75 \\ 5.52 & 1.70 \\ 5.84 & 1.96 \\ 5.69 & 1.89 \\ 5.47 & 1.57 \\ 51.46 & 1.57 \\ 5.43 & 1.73\end{array}$

1.60
1.96
1.75
1.70
1.96
1.89
1.57
1.57
1.73

1.00

1.00

0.99

1.00

1.00

0.99

0.99

$-0.36$

5,60

10,60

10,90

$5,60,120$

$10,60,120$

5.43

\subsection{0}

tandard

15

5,60

5.90

10,60

10,90

10,120

$5,60,120$

$10,60,120$

$\begin{array}{ll}5.70 & 1.70 \\ 5.98 & 1.65 \\ 5.65 & 1.84 \\ 5.49 & 1.64 \\ 5.94 & 1.66 \\ 5.61 & 1.85 \\ 5.45 & 1.65 \\ 5.50 & 1.66 \\ 5.47 & 1.65\end{array}$

1.00

0.99

0.96

0.99

0.99

0.98

0.99

$-0.15$

- 0.10

$-0.36$

$-0.29$

$+0.03$

$+0.01$

$-0.13$

$+0.05$

$-0.14$

$+0.06$

$+0.04$

$-0.25$

$=0.05$

$-0.04$

$-0.06$ 


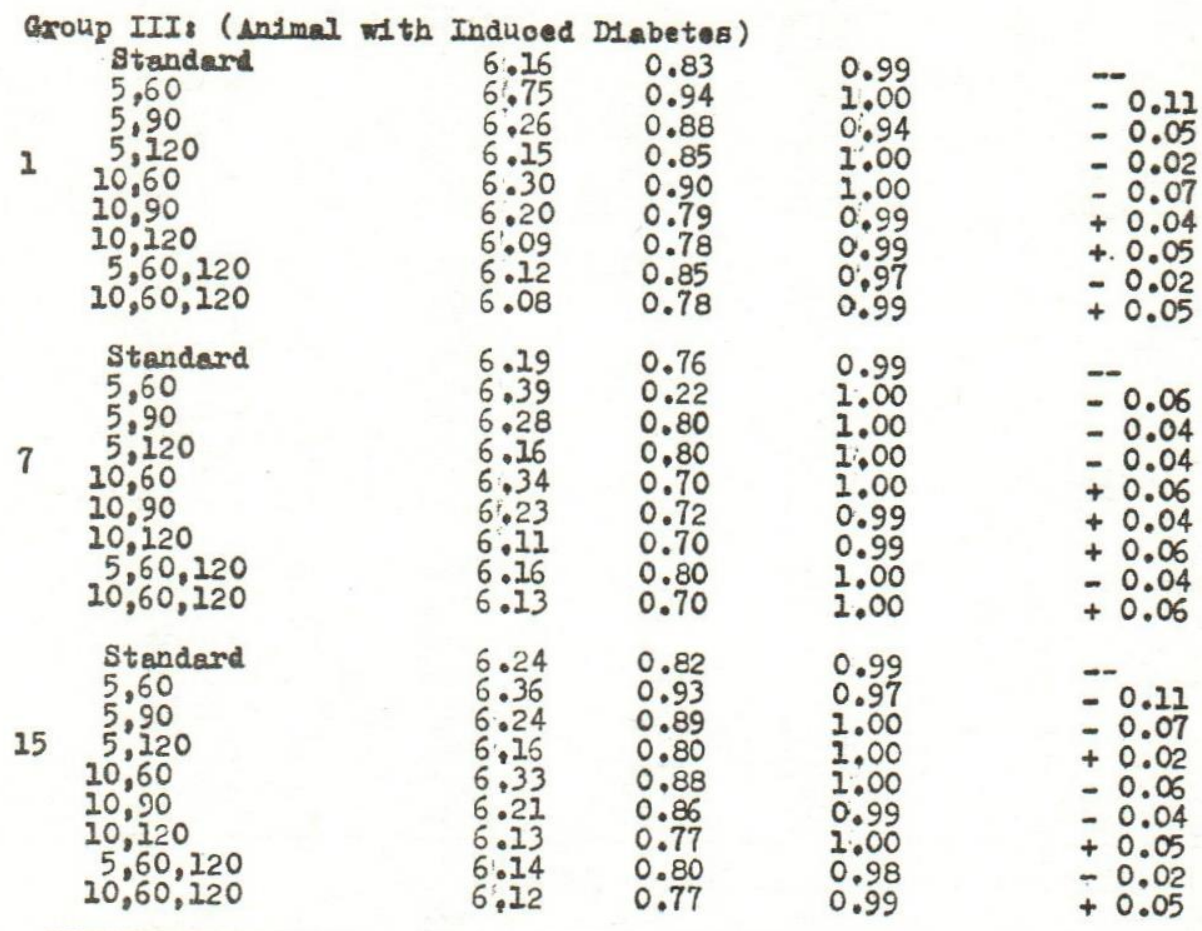

Simplified $K$ velues for the high-dose interavenoug glucose tolerance teat as compalred with the corresponding standard $K$ values

$\alpha=$ In of glucose at time 0 .

$K_{2}=$ glucose disappearance coeffloient.

$R^{2}$ corrolation coefloient 